\title{
Biosynthesis of Isoprenoids: Characterization of a Functionally Active Recombinant 2-C-methyl-D-erythritol 4-phosphate Cytidyltransferase (IspD) from Mycobacterium tuberculosis H37Rv
}

\author{
Wenjun Shi ${ }^{1,2}$, Jianfang Feng ${ }^{3}$, Min Zhang ${ }^{1}$, Xuhui Lai ${ }^{1}$, Shengfeng Xu${ }^{1}$, Xuelian Zhang ${ }^{1, *}$ and Honghai Wang ${ }^{1, *}$ \\ ${ }^{1}$ State Key Laboratory of Genetic Engineering, Institute of Genetics, School of Life Sciences, Fudan University, \\ 220 Handan Road, Shanghai 200433, P. R. China \\ ${ }^{2}$ Medical School, Tongji University, 1239 Siping Road, Shanghai, 200092, P. R. China \\ ${ }^{3}$ Pharmaceutical Division, Shanghai Institute of Pharmaceutical Industry, 1111 Zhong Shan No.1 Road (N), Shanghai, 200437, P. R. China
}

Received 22 May 2007, Accepted 4 July 2007

Tuberculosis, caused by Mycobacterium tuberculosis, continues to be one of the leading infectious diseases to humans. It is urgent to discover novel drug targets for the development of antitubercular agents. The 2-C-methyl-Derythritol-4-phosphate (MEP) pathway for isoprenoid biosynthesis has been considered as an attractive target for the discovery of novel antibiotics for its essentiality in bacteria and absence in mammals. MEP cytidyltransferase (IspD), the third-step enzyme of the pathway, catalyzes MEP and CTP to form 4-diphosphocytidyl-2-C-methylerythritol (CDP-ME) and PPi. In the work, ispD gene from M. tuberculosis H37Rv (MtIspD) was cloned and expressed. With N-terminal fusion of a histidine-tagged sequence, MtIspD could be purified to homogeneity by one-step nickel affinity chromatography. MtIspD exists as a homodimer with an apparent molecular mass of $52 \mathrm{kDa}$. Enzyme property analysis revealed that MtIspD has high specificity for pyrimidine bases and narrow divalent cation requirements, with maximal activity found in the presence of CTP and $\mathrm{Mg}^{2+}$. The turnover number of MtIspD is $3.4 \mathrm{~s}^{-1}$. The Km for MEP and CTP are 43 and $92 \mu \mathrm{M}$, respectively. Furthermore, MtIspD shows thermal instable above $5^{\circ} \mathrm{C}$.

\footnotetext{
Abbreviations: MEP, 2-C-methyl-D-erythritol 4-phosphate; CDPME, 4-diphosphocytidyl-2-C-methylerythritol; MtIspD, IspD from Mycobacterium tuberculosis; EcIspD, IspD from Escherichia coli; CjIspDF, IspDF from Campylobacter jejuni; ScIspD, IspD from Streptomyces coelicolor; AtIspD, IspD from Arabidopsis thaliana; IspDF from Mesorhizobium loti; AtIspDF, IspDF from Agrobacterium tumefaciens; IPTG, isopropyl- $\beta$-D-thiogalactopyranoside; $\mathrm{CD}$, circular dichroism
}

*To whom correspondence should be addressed. Tel: 8621 65643777; Fax: 862165648376 E-mail: hhwang@fudan.edu.cn (H. Wang) xuelianzhang@fudan.edu.cn (X. Zhang)
Circular dichroism spectra revealed that the alteration of tertiary conformation is closely related with sharp loss of enzyme activity at higher temperature. This study is expected to help better understand the features of IspD and provide useful information for the development of novel antibiotics to treat $M$. tuberculosis.

Keywords: Circular dichroism, Enzyme, Mycobacterium tuberculosis, MEP pathway, MEP cytidyltransferase

\section{Introduction}

Tuberculosis (TB), infected with Mycobacterium tuberculosis, remains the leading infectious disease to humans. It accounts for approximately 8 million new cases worldwide and an estimated 2 million deaths annually. The emergence of multidrug resistant strains and their synergy with HIV infection have fuelled spread of the disease. Accordingly, there is an urgent need to identify new drug targets and develop inhibitors against the pathogen.

Isopentenyl diphosphate (IPP) or its isomer dimethylallyl diphosphate (DMAPP) is the common precursor in the synthesis of various isoprenoid compounds. IPP was traditionally known to be synthesized from the mevalonate pathway, which begins with the condensation of three molecules of acetyl-CoA. However, the existence of an alternative pathway, known as the 2-C-methyl-Derythritol 4-phosphate (MEP) pathway, was established relatively recently. The enzymes and intermediates of the MEP pathway are completely distinct from those of the classical mevalonate pathway (Fig. 1). The pathway utilizes pyruvate (1) and Dglyceraldehyde 3-phosphate (2) as starting materials to yield 1deoxy-D-xylulose 5-phosphate (3, DXP) (Sprenger et al., 1997; Lois et al., 1998). This intermediate is reductively rearranged to 
<smiles>CC(=O)C(=O)O</smiles>

1<smiles>C=C(C)[C@H](O)COP(=O)([O-])OC[C@H](O)[C@@H](O)C(C)=O</smiles>

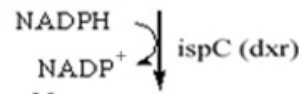<smiles>C[C@@](O)(CO)[C@@H](O)COP(=O)([O-])[O-]</smiles>

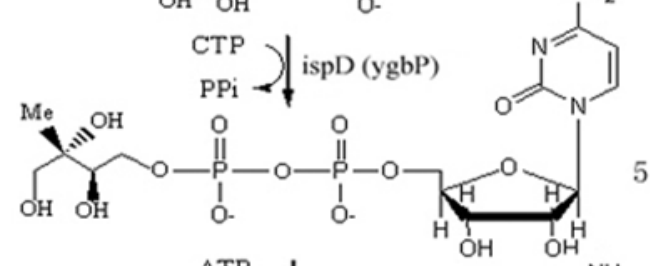

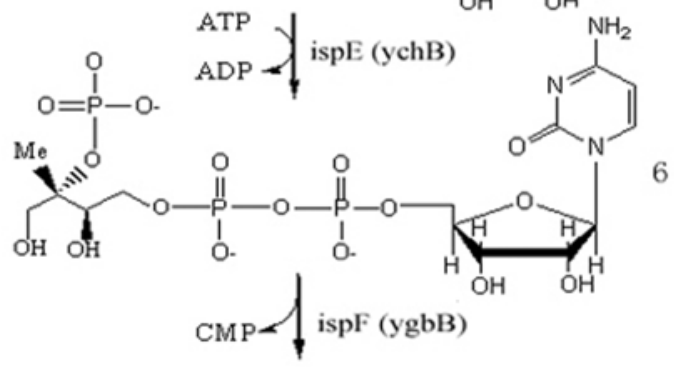

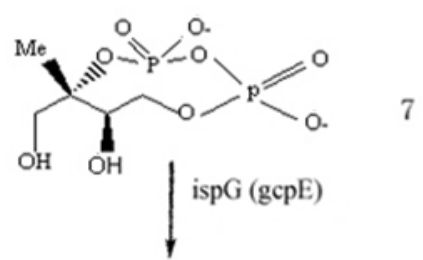<smiles>C=C(C)CCOP(=O)(O)OC(C)(C)C</smiles><smiles>CCCCCCC(=O)OP(=O)(O)O</smiles><smiles>CC(C)=CCOP(=O)(O)OP(=O)(O)O</smiles>

Fig. 1. The MEP pathway of isoprenoid biosynthesis.

2-C-methyl-D-erythritol 4-phosphate (4, MEP) by DXP reductoisomerase (DXR or IspC) (Kuzuyama et al., 1998b). MEP is further converted to 4-diphosphocytidyl-2-C-methylerythritol (5, CDP-ME) by MEP cytidyltransferase (IspD) (Rohdich et al., 1999; Kuzuyama et al., 2000a). In the following reaction steps, CDP-ME is phosphorylated by CDP-ME kinase (IspE) to produce 4-diphosphocytidyl-2-C-methyl-D-erythritol 2phosphate (6, CDP-MEP) (Kuzuyama et al., 2000b; Luttgen et al., 2000), which is cyclized to 2-C-methyl-D-erythritol-2, 4- cyclodiphosphate (7, MECP) by MECP synthase (IspF) (Herz et al., 2000; Takagi et al., 2000). The ring of the cyclodiphosphate 7 is reductively opened to yield 1-hydroxy-2-methyl-2(E)-butenyl4-diphosphate (8) (Hecht et al., 2001; Seemann et al., 2002; Altincicek et al., 2001b). Finally, LytB (IspH) tranforms 8 to a mixture of IPP (9) and DMAPP (10) (Cunningham et al., 2000; Altincicek et al., 2001a; Rohdich et al., 2002).

It has been fully established that the MEP pathway is the only source of isoprenoids in a number of eubacteria, green algae, chloroplasts of higher plants and apicoplasts of apicomplexan parasites (Rohmer et al., 1993; Jomaa et al., 1999). The essential nature of the MEP pathway in these organisms and absence in mammals make enzymes of the pathway attractive targets for the development of herbicides, antibiotics and antimalarial drugs (Freiberg et al., 2001; Cornish et al., 2006; Estévez et al., 2000). So far, the antibiotic fosmidomycin and its derivative of FR 900098 have been demonstrated to inhibit the second-step enzyme of the MEP pathway (IspC) and perform well in clinical trials against Plasmodium falciparum (Kuzuyama et al., 1998a; Lell et al., 2003).

In mycobacteria, the MEP pathway leads to the precursors of menaquinone and polyprenyl phosphates (Pol-P). Menaquinone is the electron transporter in mycobacterial respiratory chain (Jones et al., 1975). Pol-P are building blocks for the special cell wall components of mycobacteria, such as peptidoglycanarabinogalactan-mycolic acid complex as well as lipomannan and lipoarabinomannan (Wolucka et al., 1994). Thus, the reactions involved in the MEP pathway should represent excellent potential target sites for chemotherapy against $M$. tuberculosis. The properties of the enzymes involved in the pathway would provide important information for the design of novel antitubercular agents.

MEP cytidyltransferase (IspD, EC 2.7.7.60) is the third-step enzyme of the MEP pathway, and catalyzes MEP and CTP to form CDP-ME and PPi. The encoding gene ispD neighbours ispF in the genomes, which is fairly different from dispersed distribution of other genes in the MEP pathway. Gene IspD and $I s p F$ are transcriptionally coupled or, in a few bacteria species, encode together for a bifunctional enzyme (Gabrielsen et al., 2004b). This bifunctional IspDF enzyme is quite special because it catalyzes nonconsecutive steps in the pathway. It implied that IspD had physical association with both IspE and IspF, which may have a role of regulation and organization of the MEP pathway. Thus, biophysical and biochemical properties of IspD would be helpful for deciphering the mechanisms and designing drugs. So far, IspD has been cloned and partially characterized from several sources (Rohdich et al., 1999; Cane et al., 2001; Rohdich et al., 2000), only gram-negative Campylobacter jejuni is pathogen (Gabrielsen et al., 2004b). Specially, C. jejuni produces a bifunctional IspDF. No information about monofuctional IspD from other pathogenic bacterium has been characterized. According to the genome annotation, pathogenic M. tuberculosis $\mathrm{H} 37 \mathrm{Rv} \mathrm{IspD}$ and IspF genes encode a monofuctional protein, respectively. In this report, we cloned and expressed M. tuberculosis $\mathrm{H} 37 \mathrm{Rv} \mathrm{IspD}$ 
gene $(\operatorname{Rv} 3582 \mathrm{c})$ in E. coli system, and biochemical and enzymatic characterizations of the recombinant protein were determined. This study is expected to help better understand the features of monofuctional IspD from pathogen, and provide useful information for the development of novel antibiotics to treat $M$. tuberculosis.

\section{Materials and Methods}

Materials. All chemicals were purchased from Sigma Chemical Co unless stated otherwise. MEP was from Echelon Biosciences. Plasmid pET28a expression vector, E. coli DH5 $\alpha$ and BL21(DE3) strains were obtained from Novagen. The genome of $M$. tuberculosis $\mathrm{H} 37 \mathrm{Rv}$ was from our lab.

Cloning of M. tuberculosis IspD gene. The coding region of the IspD gene from $M$. tuberculosis $\mathrm{H} 37 \mathrm{Rv}$ genome was amplified by PCR with the following primers: Forward, 5'-TGGAACTCATATG GTCAGGGAAGCGGGC-3'; Reverse, 5'-CCTCTCGAGTTCACC CGCGCACTATAGCT-3'. The NdeI and XhoI sites (underlined) were introduced, respectively. The PCR reaction was performed as follows: $94^{\circ} \mathrm{C}(2 \mathrm{~min})$ for $1 \mathrm{cycle}$, followed by $94^{\circ} \mathrm{C}(15 \mathrm{~s})$ and $68^{\circ} \mathrm{C}$ $(75 \mathrm{~s})$ for 25 cycles, and $68^{\circ} \mathrm{C}(2 \mathrm{~min})$ for 1 cycle. The $\sim 700 \mathrm{bp}$ amplification was purified and digested with $N d e I$ and XhoI endonucleases (TaKaRa), then subcloned into the plasmid pET28a. The ligation mixture was transformed into E. coli $\mathrm{DH} 5 \alpha$, and positive colonies were screened on LB agar plates in the presence of $50 \mu \mathrm{g} / \mathrm{ml}$ kanamycin. Constructs possessing the correct insert were chosen on the basis of restriction digests with $N d e \mathrm{I} / X h o \mathrm{I}$, and confirmed by automated DNA sequencing using ABI 377 analyzer (Applied Biosystems). The desired plasmid was designated as pET28a-MtIspD.

Sequence analysis. Blast analysis shows similarities between MtIspD orthologs. Multiple alignments were performed among IspD sequences from major pathogenic bacteria using ClustalW at http://www.ebi. ac.uk/clustalw/. The output of alignment was edited with the GeneDoc program. The phylogenetic tree was constructed using MEGA 3.1 with the neighbor-joining (NJ) method. Sequences were selected mainly from those that the recombinant IspD proteins had been reported. In the analysis, the gaps were deleted, and a 1000 bootstrap procedure was used to test the robustness of the node on the tree. The secondary structure prediction was done using the program JPRED (http://www.combio.dundee.ac.uk/ www-jpred/) and GOR 4 (http://npsa-pbil.ibcp.fr/cgi-bin/npsa_automat.pl?page= npsa_gor4.html).

Expression and purification of MtIspD. The plasmid pET28aMtIspD was transformed into competent E. coli BL21(DE3). Bacteria cells were grown in LB broth supplemented with $50 \mu \mathrm{g} / \mathrm{ml}$ kanamycin. The culture was incubated at $37^{\circ} \mathrm{C}$ with vigorous shaking. At an optical density (600 nm) of 0.5 0.6, IPTG was added to a final concentration of $1 \mathrm{mM}$, and the culture was further incubated at $16^{\circ} \mathrm{C}$ for $12 \mathrm{~h}$. The cells were harvested by centrifugation and stored at $-80^{\circ} \mathrm{C}$. Cell pellets were thawed and re-suspended in lysis buffer (50 mM Tris-HCl, pH 8.0, $300 \mathrm{mM} \mathrm{NaCl}, 5 \mathrm{mM}$ imidazole) containing $1 \mathrm{mg} / \mathrm{ml}$ lysozyme. The mixture was incubated at $4^{\circ} \mathrm{C}$ for $30 \mathrm{~min}$ and subsequently sonicated on ice. The crude lysate was centrifuged at $16,000 \mathrm{rpm}$ at $4^{\circ} \mathrm{C}$ for $60 \mathrm{~min}$ to remove cellular debris. The supernatant was loaded on a Ni-NTA resin column (Novagen) pre-equilibrated with lysis buffer. The column was washed with 20 bed volumes of wash buffer A (50 mM Tris- $\mathrm{HCl}$, $\mathrm{pH} 8.0,300 \mathrm{mM} \mathrm{NaCl}, 20 \mathrm{mM}$ imidazole), 20 bed volumes of wash buffer B ( $50 \mathrm{mM}$ Tris- $\mathrm{HCl}, \mathrm{pH} 8.0,300 \mathrm{mM} \mathrm{NaCl}, 50 \mathrm{mM}$ imidazole) and 2 bed volumes of wash buffer $\mathrm{C}(50 \mathrm{mM}$ Tris- $\mathrm{HCl}$, pH 8.0, $300 \mathrm{mM} \mathrm{NaCl}, 100 \mathrm{mM}$ imidazole). The recombinant protein was eluted with elution buffer $(50 \mathrm{mM}$ Tris- $\mathrm{HCl}, \mathrm{pH} 8.0$, $300 \mathrm{mM} \mathrm{NaCl}, 200 \mathrm{mM}$ imidazole). The eluted protein was dialyzed overnight against $5 \mathrm{mM}$ Tris- $\mathrm{HCl}, \mathrm{pH} 8.0$ and concentrated by ultrafiltration using a $10-\mathrm{kDa}$ molecular mass cutoff filter (Millipore). The protein concentration was determined by Bradford method using bovine serum albumin (BSA) as standard. The purified protein was divided into aliquots before storage at $-80^{\circ} \mathrm{C}$. All the purification procedures were conducted at $4^{\circ} \mathrm{C}$.

Mass spectral investigation of MtIspD. The LC/MS system comprises an HP 1100 LC system (HP) with an API 165 mass spectrometer (PE). $100 \mu \mathrm{l}$ purified MtIspD sample was separated with a reverse phase column $\mathrm{C} 18(4.6 \times 250 \mathrm{~mm})$ (Agilent) using $0.1 \%$ trifluoroacetic acid (TFA) followed by an increasing linear gradient of $80 \%$ isopropanol in $0.085 \%$ TFA at a flow rate of 1.0 $\mathrm{ml} / \mathrm{min}$. Fractions were collected across the peak and analyzed by mass spectrometry. The scan mass range was from $m / z 300$ to 3000 .

Native Gel Electrophoresis of MtIspD. The native molecular mass of MtIspD was evaluated using nondenaturing electrophoresis. Protein standards were $\alpha$-lactalbumin $(14.2 \mathrm{kDa})$, carbonic anhydrase (29 kDa), chicken egg albumin (45 kDa), and bovine serum albumin (monomer, $66 \mathrm{kDa}$, and dimer, $132 \mathrm{kDa}$ ). Protein standards and purified MtIspD were electrophoresed on a set of nondenaturing gels with polyacrylamide concentrations of $6,7,8,9$, or $10 \%$, respectively. Electrophoresis was carried out at $80 \mathrm{~V}$ for $40 \mathrm{~min}$ and at $140 \mathrm{~V}$ for $2 \mathrm{~h}$. The tracking dye was bromophenol blue. Proteins were visualized after staining with Coomassie blue R-250. The relative mobility $\left(\mathrm{R}_{\mathrm{f}}\right)$ of the protein was determined by the distance of the protein migration relative to the tracking dye migration. A value of $100\left[\log \left(R_{f} \times 100\right)\right]$ for each protein was plotted against the percent concentration of acrylamide and the slope of the line was determined. The negative slope obtained for each protein was then plotted against the native molecular masses of protein standards to produce a linear $\log / \log$ plot from which the molecular mass of MtIspD was extrapolated.

Enzymatic characterization of MtIspD. MtIspD catalyzes MEP and CTP to form CDP-ME and PPi. Enzyme activity was assayed by using an inorganic pyrophosphatase-coupled assay as described by C. Bernal et al. (Bernal et al., 2005). In the method, the product PPi is further hydrolyzed by inorganic pyrophosphatase to produce inorganic phosphate, which forms a complex with ammonium molybdate-malachite green spectrometrically detectable at $630 \mathrm{~nm}$. All assays were conducted at $30^{\circ} \mathrm{C}$ in a $96-$ well plate system. The standard assay system consisted of $50 \mathrm{mM}$ Tris- $\mathrm{HCl}, \mathrm{pH}$ 8.0, $2 \mathrm{mM}$ $\mathrm{MgCl}_{2}, 2 \mathrm{mM}$ DTT, $1 \mathrm{mM}$ MEP, $1 \mathrm{mM}$ CTP, $0.1 \mathrm{U} / \mathrm{ml}$ inorganic pyrophosphatase and $5 \mu \mathrm{l}$ enzymes in a final volume of $40 \mu \mathrm{l}$. All of the components except for MtIspD were premixed and pre- 
incubated at $30^{\circ} \mathrm{C}$ for $10 \mathrm{~min}$ to reach a stable background. The MtIspD was added in the mixture to trigger the reaction. The reaction was carried out at $30^{\circ} \mathrm{C}$ for $15 \mathrm{~min}$ and terminated by addition of $40 \mu \mathrm{l}$ ammonium molybdate/malachite green dye reagent and $120 \mu \mathrm{l}$ distilled water. This final mixture was equilibrated at $30^{\circ} \mathrm{C}$ for $10 \mathrm{~min}$ and detected at $630 \mathrm{~nm}$ using a microtiter plate reader (Thermo, Waltham, USA). Inorganic phosphate production was quantified by comparing absorbance to calibration curve of $\mathrm{KH}_{2} \mathrm{PO}_{4}$.

The kinetic parameters were determined according to the published method. Effects of $\mathrm{pH}$, divalent cations, nucleotide triphosphates and temperature on enzyme activity were also determined. All results shown were the average of three different experiments.

Circular dichroism spectrum investigation of MtIspD. All the circular dichroism (CD) assays were carried out using a JASCO J715 spectropolarimeter (Jasco) with a temperature controller (Naslab). The path lengths were $0.1 \mathrm{~cm}$ for far-UV $(190-240 \mathrm{~nm})$ and $1 \mathrm{~cm}$ for near-UV (250-320 nm). The MtIspD concentration was $0.2 \mathrm{mg} /$ $\mathrm{ml}$ for far-UV and $2.0 \mathrm{mg} / \mathrm{ml}$ for near-UV. The effect of temperatures on MtIspD was investigated from $25^{\circ} \mathrm{C}$ to $80^{\circ} \mathrm{C}$. At each given temperature, $10 \mathrm{~min}$ being allowed for equilibration before the spectrum was recorded. Five scans were averaged to obtain each final spectrum. Buffer background was subtracted from the original spectra. Data were expressed in terms of molar ellipticity [ $\theta]$ in deg $\mathrm{cm}^{2} \mathrm{dmol}^{-1} \mathrm{~s}$. Secondary structure parameters were determined by the computer program PROSEC derived by Yang and coworkers (Yang et al., 1986)

\section{Results and Discussion}

Sequence analysis of MtIspD. MtIspD was subjected to alignment with the predicted sequences of IspD from several pathogenic bacteria (Fig. 2A). Two conserved motif AAGX $\mathrm{GXRX}_{5} \mathrm{PK}$ and [V/I]L[V/I]HDXAR were found in MtIspD. The glycine-rich motif, AAGXGXRX ${ }_{5} \mathrm{PK}$, coupled with Gly 82, Asp 83 and Ser 88 sequesters CTP and CDP-ME in the active site (Richard et al., 2001). However, the leeway was found in IspD sequences from M. tuberculosis and M. bovis, in which strictly conserved Ser 88 was conservatively replaced by threonine. (V/I)L(V/I)HDXAR is a characteristic signature motif of IspD. The key residues of Arg 20, Lys 27, Arg 157 and Lys 215 conserved in MtIspD are major contributors to the enzyme mechanism of which the basic side chains are involved in binding and processing substrates (Richard et al., 2001; Kemp et al., 2003).

BLAST analysis suggested that sequence identities among pathogenic bacteria vary from $32 \%$ to $99 \%$. The same genus of mycobacteria shares high sequence identities, eg Mycobacterium bovis (GI: 31620356, 99\% identity), Mycobacterium leprae TN (GI: 15827085, 67\% identity). MtIspD has 34\% identities with EcIspD, similar to $32 \%$ with plant AtIspD. Based on ClustalW and BLAST analysis, phylogenetic tree were constructed with NJ method (Fig. 2B). The phylogenectic tree clearly indicated that bacteria IspD can be divided into two groups. The first group includes actinomycetales species, while the second group consists of EcIspD, MIIspDF and AtIspDF. The phylogenetic tree based on the IspD generally revealed their evolutionary distances of several species, and MtIspD has much closer phylogenetic relationship with ScIspD than with EcIspD and other bifuntional IspDF proteins.

Expression and purification of MtIspD. Based on the available genome sequence of $M$. tuberculosis H37Rv, cloning of IspD gene from M. tuberculosis $\mathrm{H} 37 \mathrm{Rv}$ was performed. The IspD gene from $M$. tuberculosis H37Rv (Rv3582c) begins with a GTG codon at the initiation site for the translation of IspD protein. Since ATG, instead of GTG, is an initiation codon for efficiently translational initiation in the host E. coli BL21(DE3), we changed the GTG codon of MtispD to ATG by the forward primer. The amplified gene was subcloned into the $\mathrm{NdeI} / \mathrm{XhoI}$ sites of the plasmid pET28a. DNA sequencing confirmed that the inserted fragment was the putative gene sequence of $I s p D$ (Rv3582c).

The recombinant plasmid pET28a-MtIspD was used for heterologous expression of MtIspD in E. coli BL21(DE3) strain. To obtain high level of soluble MtIspD protein, we reduced the induction temperature to avoid formation of inclusion body. Optimal expression was obtained with $1 \mathrm{mM}$ IPTG at $16^{\circ} \mathrm{C}$ for $12 \mathrm{~h}$. With N-terminal fusion of a six-histidine tag, the recombinant MtIspD could be purified to homogeneity by onestep purification of nickel affinity chromatography. The overall yield of the purified protein was estimated to be about $2.8 \mathrm{mg}$ from 11 culture medium (Table 1). The turnover number of MtIspD is $3.4 \mathrm{~s}^{-1}$, in close to catalytic rate from the same actinomycetales species of $S$. coelicolor and slightly lower than other bacterial sources and plant A. thaliana (Table 2) (Cane et al., 2001; Rohdich et al., 1999; Gabrielsen et al., 2004b).

Determination oligomerization of MtIspD. On SDS-PAGE, the purified MtIspD indicated as a single band with an apparent molecular mass of $\sim 26 \mathrm{kDa}$ (Fig. 3A). The accurate molecular mass was further determined by mass spectrometry (Fig. 3B). The measured mass is $26112.0 \mathrm{Da}$, in consistent to the theoretical mass prediction of the protein (the calculated mass, $26105.66 \mathrm{Da}$ ). It thereby demonstrates veracity of the expressed recombinant MtIspD.

Previous X-ray structure studies presented that IspD organizes as a homodimer (Richard et al., 2001; Kemp et al., 2003; Gabrielsen et al., 2006). The core domain of each subunit is globular in shape and the subdomain resembles a curved arm to mediate dimer formation. This interlocking arms form part of the MEP binding site and organize portions of the catalytic surface responsible for cytidyltransferase activity (Richard et al., 2001). Thus, we carried out nondenaturing polyacrylamide gel electrophoresis to investigate the quaternary structure of MtIspD. Fig. 4 showed two main upper bands, which are charge isomers and correspondent to a molecular weight around $52 \mathrm{kDa}$. Still, there is a very weak band at the lower site of the gel, which exhibits a molecular weight of $26 \mathrm{kDa}$. 
(A)
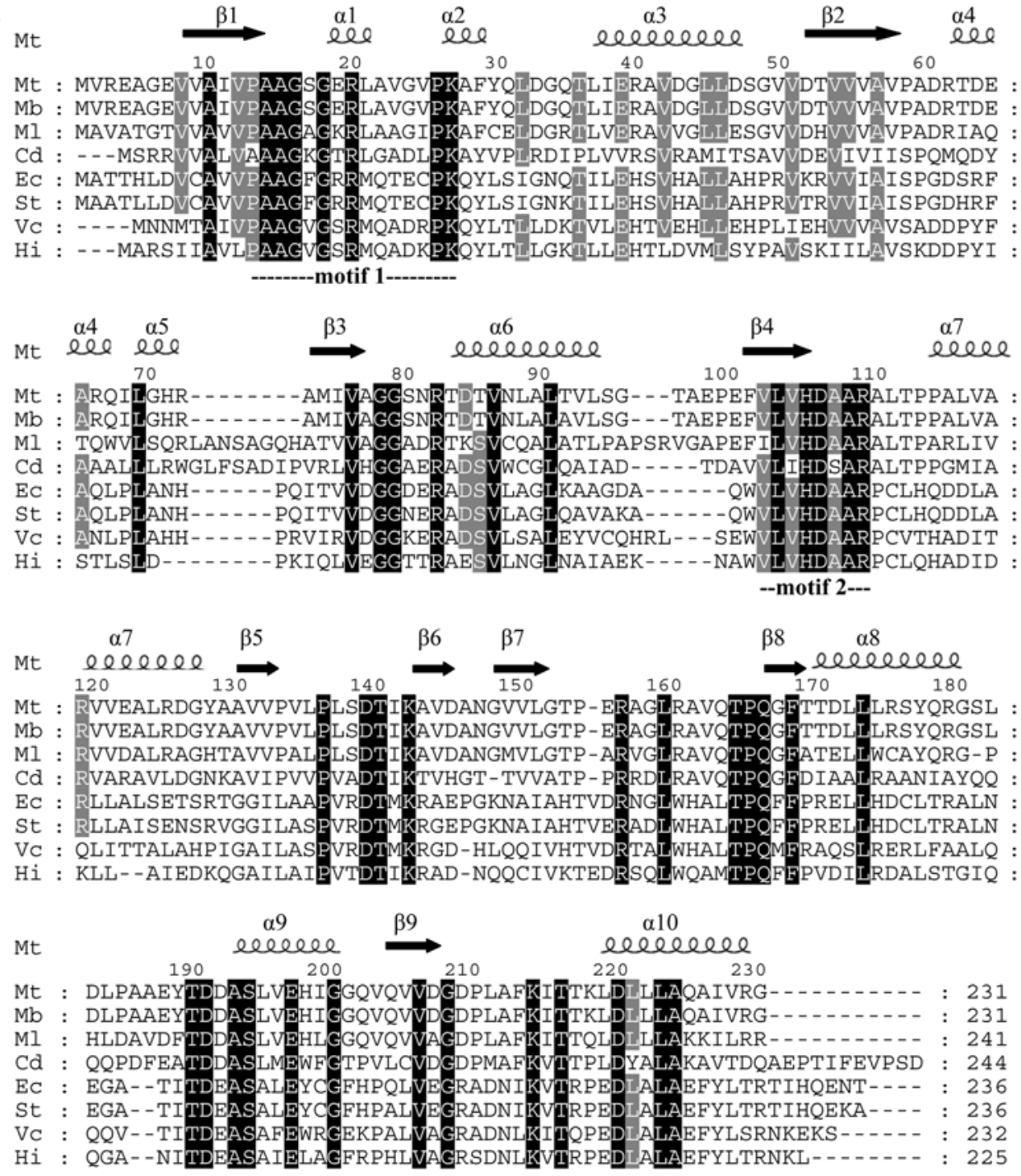

(B)

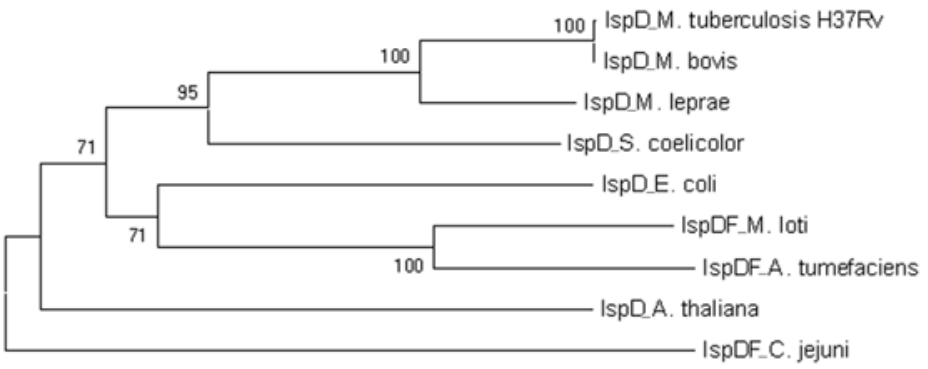

0.1

Fig. 2. Sequence analysis of MtIspD. (A) Sequence alignment of MtIspD with seven bacterium homologies. Sequences were aligned using ClustalW at http://www.ebi.ac.uk/clustalw/. Identical residues across all sequences are highlighted in black and conservative residues in gray. The conserved motifs are denoted under the sequences and secondary structures are labeled above. The species are denoted by the abbreviations as following: Mt, Mycobacterium tuberculosis H37Rv (GI:15610718); Mb, Mycobacterium bovis AF2122/97 (GI:31794759); Ml, Mycobacterium leprae TN (GI:15827085 ); Cd, Corynebacterium diphtheriae NCTC 13129 (GI:38234537); Ec, Escherichia coli K12 (GI:16130654); St, Salmonella typhi CT18 (GI:16761702); Vc, Vibrio cholerae O1 N16961 (GI:15640032); Hi, Haemophilus influenzae (GI:68249251). (B) A phylogenetic tree was constructed by MEGA 3.1 among IspD proteins which characterizations have been reported. The numbers indicate the bootstrap confidence values obtained for each node after 1000 replications. 
Table 1. Purification of the recombinant MtIspD

\begin{tabular}{lcccc}
\hline \multicolumn{1}{c}{ Steps } & Total protein $(\mathrm{mg})$ & ${\text { Total activity }(\mathrm{U})^{b}}^{b}$ & Specific acticity $(\mathrm{U} / \mathrm{mg})$ & Yield $(\%)$ \\
\hline Supernatant proteins $^{a}$ & 170 & 130 & 0.8 & 100 \\
Ni-NTA column & 2.8 & 21 & 7.5 & 16.2 \\
Concentration & 2.6 & 20.3 & 7.8 & 15.6 \\
\hline
\end{tabular}

${ }^{a}$ The supernatant proteins was from 11 culture medium.

${ }^{b}$ One unit of enzyme activity (U) is defined as the amount of enzyme that converse $1 \mu \mathrm{mol}$ substrate per minute at $30^{\circ} \mathrm{C}$.

Table 2. Comparison kinetic parameters of MtIspD with homologous IspD proteins

\begin{tabular}{|c|c|c|c|c|c|}
\hline $\begin{array}{l}\text { Recombinant protein } \\
\text { Sources }\end{array}$ & $\underset{\left(\mu \mathrm{mol} \cdot \min ^{-1} \cdot \mathrm{mg}^{-1}\right)}{\operatorname{Vmax}}$ & Kcat $\left(\mathrm{s}^{-1}\right)$ & $K m^{\mathrm{MEP}}(\mu \mathrm{M})$ & $K m^{\mathrm{CTP}}(\mu \mathrm{M})$ & References \\
\hline M. tuberculosis (MtIspD) & 7.8 & 3.4 & 43 & 92 & This study \\
\hline \multirow[t]{2}{*}{ E. coli $($ EtIspD) } & 23 & 9 & 131 & 3 & Rohdich et al., 1999 \\
\hline & 39 & 17 & 32 & $\mathrm{ND}^{a}$ & Cane et al., 2001 \\
\hline C. jejuni (CjIspDF) & 19 & 13 & 20 & 3 & Gabrielsen et al., 2004b \\
\hline S. coelicolor (ScIspD) & 13 & 6 & 3260 & 1450 & Cane et al., 2001 \\
\hline S. coelicolor (Native) ${ }^{b}$ & $2 \times 10^{-3}$ & $0.9^{c}$ & 7800 & 98 & Cane et al., 2001 \\
\hline A. thaliana (AtIspD) & 67 & 26 & 500 & 114 & Rohdich et al., 2000 \\
\hline
\end{tabular}

${ }^{a} \mathrm{ND}$, not determined.

${ }^{b}$ Enzyme from the crude, cell-free $S$. coelicolor extract.

${ }^{c} K c a t$ was calculated according the value of Vmax and provided molecular weight in the paper.

Therefore, the recombinant MtIspD is a functionally active homodimer protein. However, Gabrielsen et al. reported that EcIspD displays as monomer, dimer and unexpected tetramer by size exclusion chromatography (Gabrielsen et al, 2004a). It revealed that this tetramer is formed by dimer-dimer disulfide linkage of cysteine residue 25. We identified that Cys25 is not conservative residue among IspD family proteins, and the corresponding residue in MtIspD is valine 25. Accordingly, tetramer is not a necessary structure for IspD proteins.

Enzymatic properties of MtIspD. Enzymatic activity was evaluated by using an inorganic pyrophosphatase-coupled assay (Bernal et al., 2005). In order to investigate the apparent $K m$ of recombinant MtIspD, enzyme activity was determined by varying concentrations of one substrate while keeping concentrations of the other substrate and the recombinant enzyme constant (Fig. 5). The apparent $K m$ for MEP and CTP were 43 and $92 \mu \mathrm{M}$, respectively. The recombinant MtIspD displayed similar affinity for the substrates compared to EcIspD and CjIspD, as shown by the similar range of their $K m$ values (Table 2). Interestingly, MtIspD substrate affinities deviate form the recombinant IspD from $S$. coelicolor which had fairly low affinity for both substrates (Cane et al., 2001). Cane et al. also reported the native IspD from the crude, cellfree $S$. coelicolor extract (Cane et al., 2001). The recombinant MtIspD had almost the same $K m$ for CTP with native IspD from $S$. coelicolor, while Km for MEP is 100-folded lower than both native and recombinant IspD from $S$. coelicolor. This enzymatic property is contrast to their closer phylogenetic relationship, possibly as a result of their structural variation in the substrate binding sites.
The recombinant MtIspD had specificity for nucleotide triphosphates. GTP, UTP, and ITP could not be used as substrates; only $13 \%$ of activity was observed when CTP was replaced by ATP (data not shown). According to structure of EcIspD, this selectivity for the pyrimidine base is achieved through hydrogen bonding interactions of the glycine-rich loop and steric constrictions in the base-binding pocket that do not allow for the sequestration of larger purine bases (Richard et al., 2001). The divalent cation requirement was also evaluated (Fig. 5C). Divalent cations including $\mathrm{Mg}^{2+}, \mathrm{Mn}^{2+}$, $\mathrm{Co}^{2+}$ or $\mathrm{Fe}^{2+}$ support enzyme activities, the maximal activity was found with $\mathrm{Mg}^{2+}$. The addition of $2 \mathrm{mM}$ EDTA decreases enzyme activity. Obviously, MtIspD is a metal-dependent enzyme and $\mathrm{Mg}^{2+}$ is a preferential cofactor. This is in line with other monofunctional enzymes of EcIspD and AtIspD (Rohdich et al., 1999; Rohdich et al., 2000). However, the bifunctional enzyme $\mathrm{CjIspDF}$ is different from these. It is catalytically active in the presence of various divalent cations, with $\mathrm{Zn}^{2+}$ supporting the maximal activity (Gabrielsen et al., 2004b).

The enzyme activity was analyzed in $50 \mathrm{mM}$ Tris- $\mathrm{HCl}$ at $\mathrm{pH}$ range of $6.0 \sim 9.0$. The optimal $\mathrm{pH}$ for this reaction is 8.0 (data not shown). The thermal stability of MtIspD was also investigated. Fig. 5D presented that the recombinant MtIspD lost enzyme activity sharply after pre-incubation for $10 \mathrm{~min}$ above $50^{\circ} \mathrm{C}$, and almost all of activity was abolished at $80^{\circ} \mathrm{C}$. It suggested that MtIspD is thermal instable. This phenomenon is opposite to the stability of MtIspD at low temperature. The purified MtIspD is stable to freezing and maintained its activity for at least one month when stored at $4^{\circ} \mathrm{C}$ and for several months at $-80^{\circ} \mathrm{C}$. 

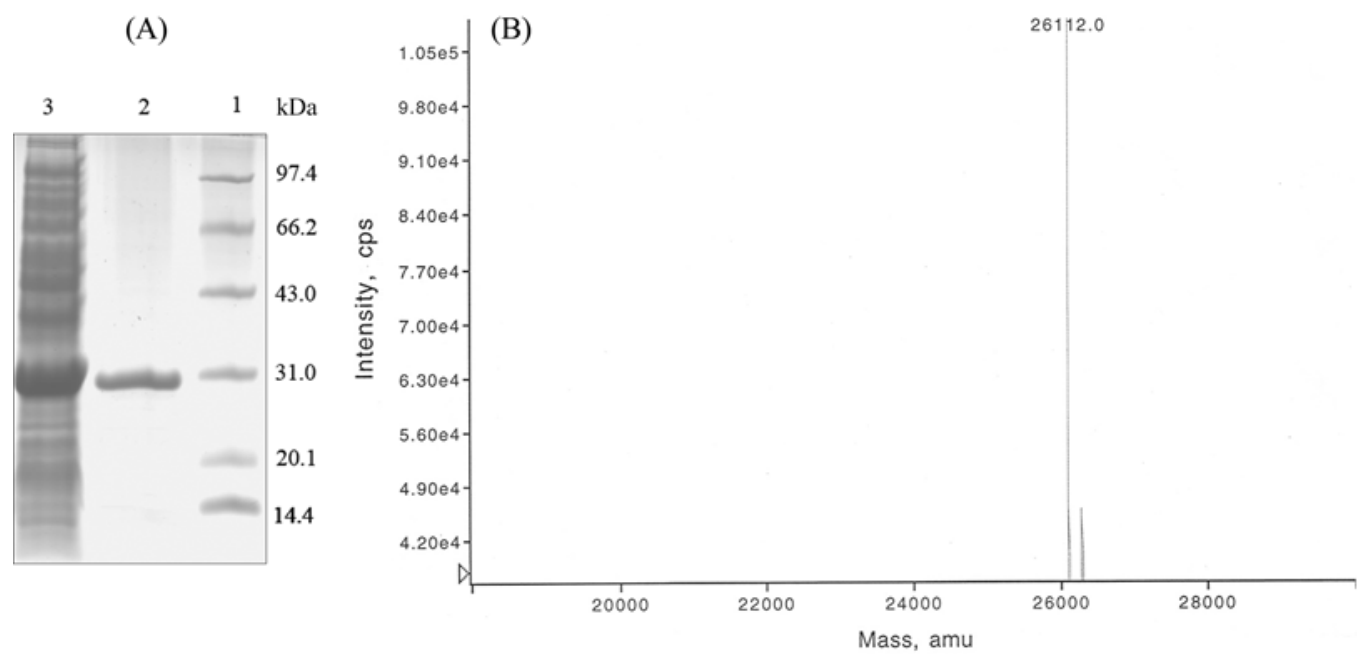

Fig. 3. Purification of MtIspD. (A) SDS-PAGE assay of the purified MtIspD protein. lane 1, molecular mass marker; lane 2, purified recombinant MtIspD; lane 3, boiled E. coli cells containing pET28a-MtispD after induction period with $1 \mathrm{mM}$ IPTG (B) Mass spectrum analysis of MtIspD.
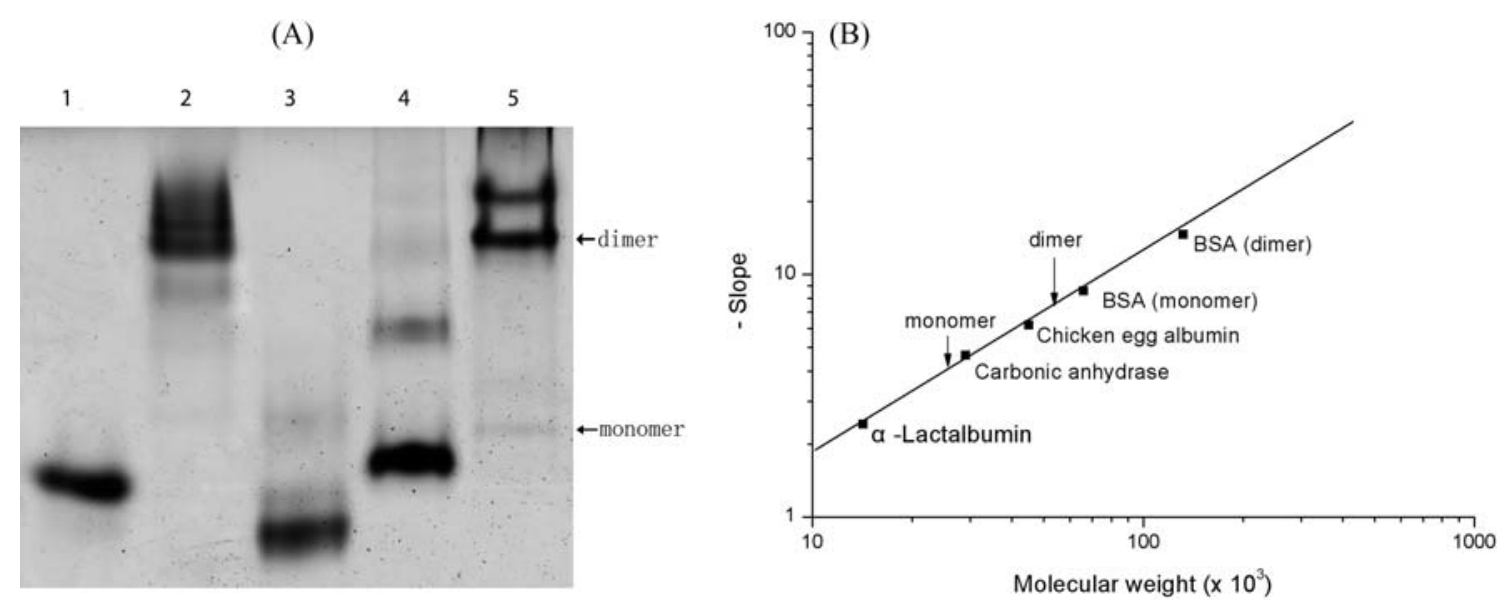

Fig. 4. Estimation of the molecular weight of MtIspD. (A) MtIspD and standard proteins were submitted to polyacrylamide gel electrophoresis under nondenaturing conditions in gels of different polyacrylamide concentration. A nondenaturing electrophoresis gel with $7 \%$ polyacrylamide was presented. (1) $\alpha$-lactalbumin (14.2 kDa), (2) carbonic anhydrase (29 kDa), (3) chicken egg albumin (45 kDa), (4) bovine serum albumin (monomer, $66 \mathrm{kDa}$, and dimer, $132 \mathrm{kDa}$ ), (5) MtIspD. (B) A plot of the negative slopes versus the known molecular weights of the standards, from which the molecular weight of MtIspD was determined.

Structural properties of MtIspD. Circular dichroism (CD) spectroscopy, the most widely used chiroptical method, has an extreme sensitivity toward protein structure. In order to examine whether conformational changes are responsible for thermal instability of the recombinant MtIspD, we determined the secondary and tertiary structures of $\mathrm{MtIspD}$ at the temperature range of $25-80^{\circ} \mathrm{C}$ by the far-UV and near-UV CD spectra respectively (Fig. 6).

For the far-UV spectra, MtIspD exhibited similar two negative extrema in the vicinity of 208 and $222 \mathrm{~nm}$, one positive extremum at $193 \mathrm{~nm}$, which are characteristic spectra of $\alpha+\beta$ or $\alpha / \beta$ proteins (Venyaminov et al. 1994). Analysis of CD spectrum at $25^{\circ} \mathrm{C}$ indicated that the secondary structures for $\alpha$ helix, $\beta$-sheet, $\beta$-turn and random coil were 33.4, 26.6, 11.0 and $29.0 \%$, respectively. Generally, CD spectrum provides more precise estimates for á-helix (Baumruk et al. 1996). This $\alpha$-helix percentage is consistent with predictions of $33.8 \%$ by GOR 4 and $36.4 \%$ by JPRED software. It also matches to $33.2 \% \alpha$-helix derived from x-ray analysis of EcIspD threedimensional structure (Richard et al. 2001). Therefore, it is indicative of the native-folded structures of the recombinant MtIspD.

As increments of temperatures, MtIspD displays similar pattern of spectra in far-UV region, only with minor changes in the proximity to $193 \mathrm{~nm}$ and $222 \mathrm{~nm}$, revealing that MtIspD still partly keeps the integrity of secondary structure at higher temperature from $50^{\circ} \mathrm{C}$ to $80^{\circ} \mathrm{C}$ In near-UV region, MtIspD displays similar shapes at 25,30 and $40^{\circ} \mathrm{C}$, indicative of well- 

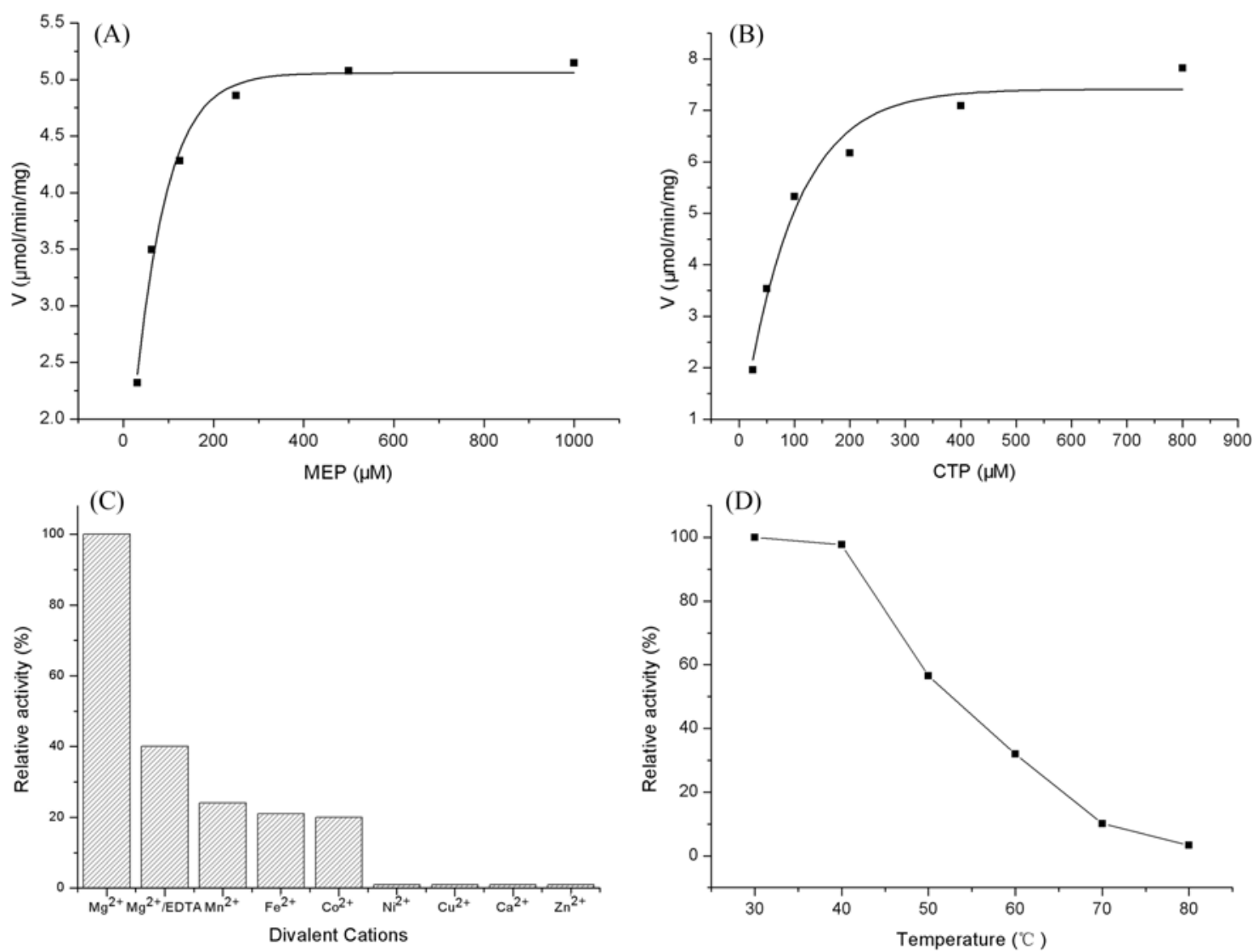

Fig. 5. Enzymatic properties of MtIspD. (A) Effects of MEP concentrations on MtIspD. CTP was held at 2 mM, with varied concentrations of MEP. (B) Effects of CTP concentrations on MtIspD. MEP was held at $2 \mathrm{mM}$, with varied concentrations of CTP. (C) Divalent cation requirements of MtIspD. Divalent cations and EDTA were added to the reaction buffer at a final concentration of $2 \mathrm{mM}$. (D) Effect of temperatures on MtIspD enzyme activity. The proteins were pre-incubated at various temperatures ranging from $30^{\circ} \mathrm{C}$ to $80^{\circ} \mathrm{C}$ for $10 \mathrm{~min}$ and chilled on ice. The residual activity was measured at $30^{\circ} \mathrm{C}$ in the standard kinetic assay system, and was expressed as a percentage of the original activity without preincubation.
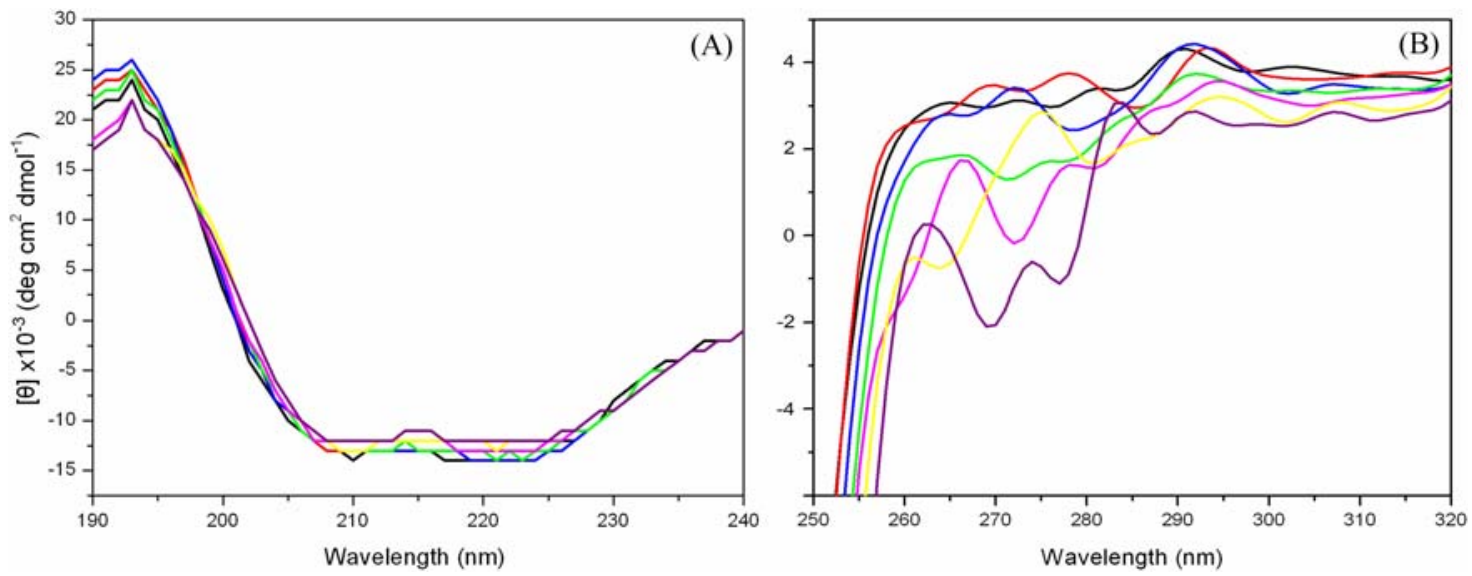

Fig. 6. CD spectra of MtIspD at the temperature range of $25-80^{\circ} \mathrm{C}$. (A) Far-UV CD spectra of MtIspD were recorded using $0.1 \mathrm{~cm}$ pathlength cell. The protein concentration was $0.2 \mathrm{mg} / \mathrm{ml}$ in $5 \mathrm{mM}$ Tris- $\mathrm{HCl} \mathrm{pH}$ 8.0. (B) Near-UV CD spectra of MtIspD were recorded using $1 \mathrm{~cm}$ path-length cell. The protein concentration was $2 \mathrm{mg} / \mathrm{ml}$ in $5 \mathrm{mM}$ Tris- $\mathrm{HCl} \mathrm{pH} \mathrm{8.0.} \mathrm{The} \mathrm{color} \mathrm{code} \mathrm{is:} \mathrm{black,} 25^{\circ} \mathrm{C}$; red, $30^{\circ} \mathrm{C}$; blue, $40^{\circ} \mathrm{C}$; green, $50^{\circ} \mathrm{C}$; magenta, $60^{\circ} \mathrm{C}$; yellow, $70^{\circ} \mathrm{C}$; purple $80^{\circ} \mathrm{C}$. 
defined, native-like tertiary structures. Upon a further increase of temperature from $50^{\circ} \mathrm{C}$ to $80^{\circ} \mathrm{C}$, less ellipticities were observed in the $260-285 \mathrm{~nm}$ region, suggesting the occurrence of a thermally-induced unfolding from $50^{\circ} \mathrm{C}$ to $80^{\circ} \mathrm{C}$. This three-dimensional conformation change above $50^{\circ} \mathrm{C}$ is consistent to enzymatic result. Thus, conformational alteration is closely related with catalytic activity loss. Since the enzymatic active site of IspD is located at the dimer interface formed by partner subunits, this thermal instability of MtIspD may possibly reflect to conformational alteration of the active site influenced by the tertiary conformational change of each subunit.

In this paper, we first described expression, purification and characterization of IspD protein from M. tuberculosis H37Rv. Our results indicated that the recombinant MtIspD is a rightfolded and functionally active homodimer protein. It shares some basic characteristics with other bacterial monofunctional IspD proteins. Still, MtIspD bears some unique features. Substrate affinities of MtIspD are distinct from its phylogenetic relationship with $S$. coelicolor. MtIspD is thermal instable above $50^{\circ} \mathrm{C}$. As MtIspD is a promising target for anti-tuberculosis drug design, the biophysical and biochemical is expected to favor better understanding MtIspD features. Therefore, our study might gain insight into structural and functional features of MtIspD and further providing possible hints in the discovery of the anti-tuberculosis compounds using MtIspD as a target.

Acknowledgments The work was supported by the Ministry of Science and Technology of China. (973 Project, No. 2002CB512804 and 30670109) and Shanghai Basic Research Project from the Shanghai Science and Technology Commission (Grant No. 06JC14012). We are grateful Dr Xiao-ping Chen and Dr Ya-lei Dai for critically reviewing the manuscript.

\section{References}

Altincicek, B., Kollas, A. K., Eberl, M., Wiesner, J., Sanderbrand, S., Hintz, M., Beck, E. and Jomaa, H. (2001a) LytB, a novel gene of the 2-C-methyl-D-erythritol 4-phosphate pathway of isoprenoid biosynthesis in Escherichia coli. FEBS Lett. 499, 37-40.

Altincicek, B., Kollas, A. K., Sanderbrand, S., Wiesner, J., Hintz, M., Beck, E. and Jomaa, H. (2001b) GcpE is involved in the 2-Cmethyl-D-erythritol 4-phosphate pathway of isoprenoid biosynthesis in Escherichia coli. J. Bacteriol. 183, 2411-2416.

Baumruk, V., Pancoska, P. and Keiderling, T. A. (1996) Predictions of secondary structure using statistical analyses of electronic and vibrational circular dichroism and Fourier transform infrared spectra of proteins in $\mathrm{H}_{2} \mathrm{O} . J$. Mol. Biol. 259, 774-791.

Bernal, C., Palacin, C., Boronat, A. and Imperial, S. (2005) A colorimetric assay for the determination of 4-diphosphocytidyl-2C-methyl-D-erythritol 4-phosphate synthase activity. Anal. Biochem. 337, 55-61.

Cane, D. E., Chow, C., Lillo, A. and Kang, I. (2001) Molecular cloning, expression and characterization of the first three genes in the mevalonate-independent isoprenoid pathway in Streptomyces coelicolor. Bioorg. Med. Chem. 9, 1467-1477.
Cornish, R. M., Roth, J. R. and Poulter, C. D. (2006) Lethal mutations in the isoprenoid pathway of Salmonella enterica. $J$. Bacteriol. 188, 1444-1450.

Cunningham, F. X., Jr., Lafond, T. P. and Gantt, E. (2000) Evidence of a role for LytB in the nonmevalonate pathway of isoprenoid biosynthesis. J. Bacteriol. 182, 5841-5848.

Estévez, J. M., Cantero, A., Romero, C., Kawaide, H., Jimenez, L. F., Kuzuyama, T., Seto, H., Kamiya, Y. and Leon, P. (2000) Analysis of the expression of CLA1, a gene that encodes the 1deoxyxylulose 5-phosphate synthase of the 2-C-methyl-Derythritol-4-phosphate pathway in Arabidopsis. Plant Physiol. 124, 95-104.

Freiberg, C., Wieland, B., Spaltmann, F., Ehlert, K., Brotz, H. and Labischinski, H. (2001) Identification of novel essential Escherichia coli genes conserved among pathogenic bacteria. $J$. Mol. Microbiol. Biotechnol. 3, 483-489.

Gabrielsen, M., Bond, C. S., Hallyburton, I., hecht, S., Bacher, A, Eisenreich, W., Rohidch, F. and Hunter, W. N. (2004a) Hexameric Assembly of the bifunctional methylerythritol 2,4cyclodiphosphate synthase and protein-protein associations in the deoxy-xylulose-dependent pathway of isoprenoid precursor biosynthesis. J. Bio. Chem. 279, 52753-52761.

Gabrielsen, M., Kaiser, J., Rohdich, F., Eisenreich, W., Laupitz, R., Bacher, A., Bond, C. S. and Hunter, W. N. (2006) The crystal structure of a plant 2C-methyl-D-erythritol 4-phosphate cytidylyltransferase exhibits a distinct quaternary structure compared to bacterial homologues and a possible role in feedback regulation for cytidine monophosphate. FEBS J. 273, 1065-1073.

Gabrielsen, M., Rohdich, F., Eisenreich, W., Grawert, T., Hecht, S., Bacher, A. and Hunter, W. N. (2004b) Biosynthesis of isoprenoids: a bifunctional IspDF enzyme from Campylobacter jejuni. Eur. J. Biochem. 271, 3028-3035.

Hecht, S., Eisenreich, W., Adam, P., Amslinger, S., Kis, K., Bacher, A., Arigoni, D. and Rohdich, F. (2001) Studies on the nonmevalonate pathway to terpenes: the role of the GcpE (IspG) protein. Proc. Natl. Acad. Sci. USA 98, 14837-14842.

Herz, S., Wungsintaweekul, J., Schuhr, C. A., Hecht, S., Luttgen, H., Sagner, S., Fellermeier, M., Eisenreich, W., Zenk, M. H., Bacher, A. and Rohdich, F. (2000) Biosynthesis of terpenoids: YgbB protein converts 4-diphosphocytidyl-2C-methyl-D-erythritol 2phosphate to 2C-methyl-D-erythritol 2,4-cyclodiphosphate. Proc. Natl. Acad. Sci. USA 97, 2486-2490.

Jomaa, H., Wiesner, J., Sanderbrand, S., Altincicek, B., Weidemeyer, C., Hintz, M., Turbachova, I., Eberl, M., Zeidler, J., Lichtenthaler, H. K., Soldati, D. and Beck, E. (1999) Inhibitors of the nonmevalonate pathway of isoprenoid biosynthesis as antimalarial drugs. Science 285, 1573-1576.

Jones, C. W., Brice, J. M., Downs, A. J. and Drozd, J. W. (1975) Bacterial respiration-linked proton translocation and its relationship to respiratory-chain composition. Eur. J. Biochem. 52, 265-271.

Kemp, L. E., Bond, C. S. and Hunter, W. N. (2003) Structure of a tetragonal crystal form of Escherichia coli 2C-methyl-Derythritol 4-phosphate cytidylyltransferase. Acta. Crystallogr. 59, 607-610.

Kuzuyama, T., Shizimu, T., Takahashi, S. and Seto, H. (1998a) Fosmidomycin, a specific inhibitor of 1-deoxy-D-xylulose 5phosphate reductoisomerase in the nonmevalonate pathway of isoprenoidbiosynthesis. Tetrahedron Lett. 39, 7913-7916.

Kuzuyama, T., Takagi, M., Kaneda, K., Tohru and Seto, H. (2000a) Formation of 4-(cytidine 5'-diphospho)-2-C-methyl-D-erythritol 
from 2-C-methyl-D-erythritol 4-phosphate by 2-C-methyl-Derythritol 4-phosphate cytidylyltransferase, a new enzyme in the nonmevalonate pathway. Tetrahedron Lett. 41, 703-706.

Kuzuyama, T., Takagi, M., Kaneda, K., Watanabe, H., Dairi, T. and Seto, H. (2000b) Studies on the nonmevalonate pathway: conversion of 4-(cytidine 5'-diphospho)-2-C-methyl-D-erythritol to its 2-phospho derivative by 4-(cytidine 5'-diphospho)-2Cmethyl-D-erythritol kinase. Tetrahedron Lett. 41, 2925-2928.

Kuzuyama, T., Takahashi, S., Watanabe, H. and Seto, H. (1998b) Direct Formation of 2-C-Methyl-D-Erythritol 4-Phosphate from 1-Deoxy-D-Xylulose 5-Phosphate by 1-Deoxy-D-Xylulose 5Phosphate Reductoisomerase, A New Enzyme in the NonMevalonate pathway to Isopentenyl Diphosphate. Tetrahedron Lett. 39, 4509-4512.

Lell, B., Ruangweerayut, R., Wiesner, J., Missinou, M. A., Schindler, A., Baranek, T., Hintz, M., Hutchinson, D., Jomaa, H. and Kremsner, P. G. (2003) Fosmidomycin, a novel chemotherapeutic agent for malaria. Antimicrob Agents Chemother. 47, 735-738.

Lois, L. M., Campos, N., Putra, S. R., Danielsen, K., Rohmer, M. and Boronat, A. (1998) Cloning and characterization of a gene from Escherichia coli encoding a transketolase-like enzyme that catalyzes the synthesis of D-1-deoxyxylulose 5-phosphate, a common precursor for isoprenoid, thiamin, and pyridoxol biosynthesis. Proc. Natl. Acad. Sci. USA 95, 2105-2110.

Luttgen, H., Rohdich, F., Herz, S., Wungsintaweekul, J., Hecht, S., Schuhr, C. A., Fellermeier, M., Sagner, S., Zenk, M. H., Bacher, A. and Eisenreich, W. (2000) Biosynthesis of terpenoids: YchB protein of Escherichia coli phosphorylates the 2-hydroxy group of 4-diphosphocytidyl-2C-methyl-D-erythritol. Proc. Natl. Acad. Sci. USA 97, 1062-1067.

Richard, S. B., Bowman, M. E., Kwiatkowski, W., Kang, I., Chow, C., Lillo, A. M., Cane, D. E. and Noel, J. P. (2001) Structure of 4diphosphocytidyl-2-C-methylerythritol synthethase involved in mevalonate-independent isoprenoid biosynthesis. Nat. Struct. Biol. 8, 641-648.

Rohdich, F., Hecht, S., Gartner, K., Adam, P., Krieger, C., Amslinger, S., Arigoni, D., Bacher, A. and Eisenreich, W. (2002) Studies on the nonmevalonate terpene biosynthetic pathway: Metabolic role of IspH (LytB) protein. Proc. Natl. Acad. Sci. USA 99, 1158-1163.

Rohdich, F., Wungsintaweekul, J., Eisenreich, W., Richter, G., Schuhr, C. A., Hecht, S., Zenk, M. H. and Bacher, A. (2000)
Biosynthesis of terpenoids: 4-diphosphocytidyl-2C-methyl-Derythritol synthase of Arabidopsis thaliana. Proc. Natl. Acad. Sci. USA 97, 6451-6456.

Rohdich, F., Wungsintaweekul, J., Fellermeier, M., Sagner, S., Herz, S., Kis, K., Eisenreich, W., Bacher, A. and Zenk, M. H. (1999) Cytidine 5'-triphosphate-dependent biosynthesis of isoprenoids: YgbP protein of Escherichia coli catalyzes the formation of 4diphosphocytidyl-2-C-methylerythritol, Proc. Natl. Acad. Sci. USA 96, 11758-11763.

Rohmer, M., Knani, M., Simonin, P., Sutter, B. and Sahm, H. (1993) Isoprenoid biosynthesis in bacteria: a novel pathway for the early steps leading to isopentenyl diphosphate. Biochem. J. 295, 517524.

Seemann, M., Campos, N., Rodriguez-Concepcion, M., Ibanez, E., Duvold, T., Tritsch, D., Boronat, A. and Rohmer, M. (2002) Isoprenoid biosynthesis in Escherichia coli via the methylerythritol phosphate pathway: enzymatic conversion of methylerythritol cyclodiphosphate into a phosphorylated derivative of (E)-2methylbut-2-ene-1,4-diol. Tetrahedron Lett. 43, 1413-1415.

Sprenger, G. A., Scho"rken, U., Wiegert, T., Grolle, S., De Graaf, A. A., Taylor, S. V., Begley, T. P., Bringer-Meyer, S. and Sahm, H. (1997) Identification of a thiamin-dependent synthase in Escherichia coli required for the formation of the 1-deoxyDxylulose 5-phosphate precursor to isoprenoids, thiamin, and pyridoxol. Proc. Natl. Acad. Sci. USA 94, 12857-12862.

Takagi, M., Kuzuyama, T., Kaneda, K., Watanabe, H., Dairi, T. and Seto, H. (2000) Studies on the nonmevalonate pathway: formation of 2-C-methyl-D-erythritol 2,4-cyclodiphosphate from 2-phospho4-(cytidine 5'-diphospho)-2-C-methyl-D-erythritol. Tetrahedron Lett. 41, 3395-3398.

Venyaminov, S. Y. and Vassilenko, K. S. (1994) Determination of protein tertiary structure class from circular dichroism spectra. Anal. Biochem. 222, 176-184.

Wolucka, B. A., McNeil, M. R., Hoffmann, E., Chojnacki, T. and Brennan, P. J. (1994) Recognition of the lipid intermediate for arabinogalactan/arabinomannan biosynthesis and its relation to the mode of action of ethambutol on mycobacteria. J. Mol. Chem. 269, 23328-23335.

Yang, J. T., Wu, C. S. and Martinez, H. M. (1986) Calculation of protein conformation from circular dichroism. Methods Enzymol. 130, 208-269. 